\title{
Sperms biometry of local Iraqi Awassi Rams
}

\author{
U. D. Naoman \\ Coll. of Vet. Med../ Univ, of Mosul \\ E-mail address:uday792001@yahoo.com
}

\begin{abstract}
This study was design to estimated of sperms biometry in local Iraqi Awassi rams. Five mature rams of 2.5-4 years old and 37-44 Kg live body weight were used in this study. Semen collection was performed by using artificial vagina. Semen samples were evaluated immediately after collection of total 30 ejaculate. Semen volume and color, mass and individual sperms motility, live and abnormal sperms as well as sperms concentration were estimated. sperms biometry calculated by using phase contrast microscope and occulo-micrometer lens.Semen biometry means which estimated in this study were; sperms head length $9.62 \pm 1.2$ micron, sperms head width $5.32 \pm 2.5$ micron, acrosome length $6.10 \pm 2.4$ micron, head base width $2.54 \pm$ 1.8 micron , midpiece length $11.92 \pm 3.6$, midpice width $2.21 \pm 0.8$ micron, tail length $50.62 \pm$ 2.1 micron.
\end{abstract}

Key words: Semen quality, Sperms Biometry, local Iraqi Awassi rams

\section{Introduction}

Sperm morphology assessment has been regarded as one of the most important factors for determining sperm quality (1). Morphologic assessment of spermatozoa is an integral component in the analysis of semen $(2,3)$. Sperms morphometry is a parameter in the evaluation of semen that has been associated with fertility $(1,4,5$, 6). Evaluating morphology as a part of a fertility study and performing breeding soundness examinations which used by technician, a veterinarian, a clinician at andrology laboratory or in artificial insemination centers (7).There were no previous information about sperms biometry of local Iraqi Awassi ram so this study was design to estimated sperms biometry of Iraqi local Awassi rams.

Material and MethodsExperimental animals: Five adult Iraqi Awassi rams of 2.5-4 years old and 37-44 Kg live body weight were used in this study. Animals were housed in the animal house, College of Veterinary Medicine, University of Mosul. This study was carried out during the period of 1-5 to 1-7- 2012.
Semen collection and evaluation: Semen collection was performed by using artificial vagina. All semen samples were analyzed immediately after collection, Semen volume and color, mass activity, sperm individual motility, percentage of live and abnormal sperms percentages and sperms concentration were estimated of total 30 ejaculate (4).

Slides fixation: One drop of fresh semen was diluted by five drops of physiological normal saline $0.9 \%$, then one drop was taken and mixed with one drop of phormalsaline solution $70 \%$ which previously prepared for fixation of the specimens until reading under microscope done. Three samples prepared from each ejaculate and at least 200 sperms morphologically analyzed in each slides (5).

Estimation of microscopic metric factor : Phase contrast microscope ( Nikon type 104C, production of Nikon corporation, 23, Maruouchi 3-chome, Chiyoda-KuTokyo, 100-8331, Japan) used to read the slides, microscope metric factor was calculated by using a known graduated stander slides which putting under oil 


\section{AL-Qadisiya Journal of Vet.Med.Sci. \\ Vol./12 \\ No./2 \\ 2013}

immersion (high power), the estimation was done in same method described by Thienpont., et al (10). The graduated line in the slides

read by using oculo-micrometer lens. The oculo-micrometer lens have a graduated line, focus continuo until getting coincidence between graduated lines of the oculo-micrometer lens with the graduated lines in the standard slides, and then the reading of the microscpe factor by using the equation:

$\mathrm{P} \times \mathrm{N} / 100=$ metric factor of the microscope in micron:-

$\mathrm{P}=$ power of emersion oil lens which equal 1.1

$\mathrm{N}=$ number of graduated lines which fully coincidence between the oculomicrometer lens and the graduated stander slides.

Calculated sperm biometry: all these parameters were done by using oculomicrometer lens (7).
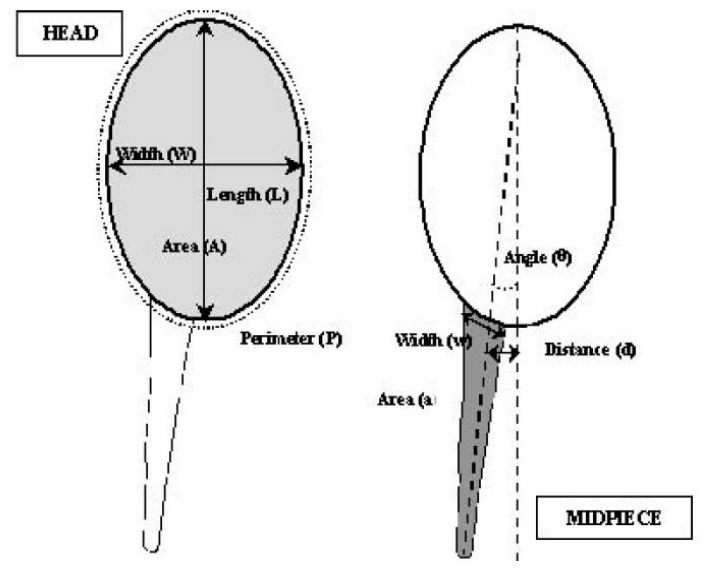

Pic 1: head morphometry which describe by Hidalgo, et al., 2005(9)

Statistical analysis: the results were expressed as means \pm SE data Data
Sperm head: Head length estimated by calculated the graduated lines between the distal point in the head acrosome to the distal point in head base, Head width was done by estimated the distance between the two equal points in the opposite side of head width, Acrosome length calculated by estimated the length by calculated distance between top of the head of sperm to the area of attachment between acrosome and nucleus of sperm head, Base of the sperm head diameter was calculated length of the attachment area between the head and midpiece $(8,10,11)$

Midpice: the length calculated by taking the distance between farness points, the first in the area which attach the head while the other in the area attached tail $(9,16)$

Tail: length of the tail calculated by estimated the distance between attachment of the tail with midpiece to the end of the free end of the tail $(9,16)$. analyzed using SPSS ( SPSS 11.5, 2 package, 2003, SPSS Inc.). 


\section{Results}

semen parameters of local Iraqi Awassi rams were summarized in table 1 . Semen volume was $1.80 \pm 0.9 \mathrm{ml}$, Sperms mass were $85.0 \pm 3.6 \%$ while sperms individual motility were $89.20 \pm 4.2 \%$.
Sperm concentration show was $3.90 \pm 1.1 \times$ $10^{9}$. Sperm live percentage was $93.10 \pm 3.1 \%$. Sperm abnormalities was $12.00 \pm 0.9 \%$.

Table 1: Semen characteristics of local Iraqi Awassi ram.

\begin{tabular}{|l|c|}
\hline Semen parameters & Means \pm SE \\
\hline Volume (ml) & $1.80 \pm 0.9$ \\
\hline Mass motility $(\%)$ & $85.0 \pm 3.6$ \\
\hline Individual motility $(\%)$ & $89.20 \pm 4.2$ \\
\hline Live sperm $\%)$ & $93.10 \pm 3.1$ \\
\hline Sperm concentration $\times 10^{9}$ & $3.90 \pm 1.1$ \\
\hline Abnormal sperm $(\%)$ & $12.00 \pm 0.9$ \\
\hline
\end{tabular}

All semen biometry data were summarized in table 2. Sperm head length was 9.62 \pm 1.2 micron, sperm width means $5.32 \pm 2.5$ micron, lengths of acrosome were $6.10 \pm 2.4$ micron. width of sperm base was 2.54 1.8 micron, Length of midpice was $11.92 \pm 3.6$ micron, midpice width was $2.21 \pm 0.8$ micron. Sperm tail length was $50.62 \pm 2.1$ micron.

Table 2 : sperm biometry of local Iraqi Awassi ram.

\begin{tabular}{|l|c|}
\hline Sperms biometry (micron) & Means \pm SE \\
\hline Head length & $9.62 \pm 1.2$ \\
\hline Head width & $5.32 \pm 2.5$ \\
\hline Acrosome length & $6.10 \pm 2.4$ \\
\hline Head base width & $2.54 \pm 1.8$ \\
\hline Midpice length & $11.92 \pm 3.6$ \\
\hline Midpice width & $2.21 \pm 0.8$ \\
\hline Tail length & $50.62 \pm 2.1$ \\
\hline
\end{tabular}

\section{Discussion}

The semen parameters of Awassi rams which records in the present study were within the physiological values for fertile local Iraqi Awassi rams and similar to data estimated by another researches (1013).Sperms biometry were recorded in this study showed in table 2, this is the first record of sperms biometry of Iraqi Awassi rams by using phase contrast microscope and occulo-micrometer lens.Sperms biometry of Iraqi Awassi rams recorded in this study were within the normal physiological values for fertile rams which agreement with recorded of $(14,15)$ in Awassi rams, the agreement may be due to sperms biometry is property relating to the species and gene express which defer from species to species $(17,20)$. Sperm biometry estimated recently by using a different techniques including computer-assisted (aid) sperm analyzer (CASA), sperm class analyzer (SCA) and light microscope $(6,8,9,18,19,20)$, but all these technique were shared in same disadvantages, 
expensive and using satins during preparation, these stains may be effect sperm biometry (especially head biometry) when this stains enter head sperm or another parts(9).Techniques were used in this study is easy, fast and don't use any stains (may be effected sperm morphology) which can be used for complete sperm evaluation and breeding soundness test of male rams, its important fixation sperm biometry of Iraqi Awassi rams index which can be used for sperm integrity and fertility(8).

\section{References}

1- Marti JI; Aparicio MI; Leal CLV. and Herreros.(2012).Sperm

morphology assessment has been regarded as one of the most important factors for determining sperm quality. Theriogenology. 78:528-541.

2- Kuster CE; Singer RS. and Althouse GC. (2004). Determining sample size for the morphological assessment of sperm. Theriogenology. 61:691-703.

3- De Paz P; Mata-Campuzano M; Jorge TE; Alvarez M; Alvarez MR; Herraez P. and Anel L. (2011). The relationship between ram sperm head morphometry and fertility depends on the procedure of acquisition and analysis used. Theriogenology. 76: 1313-1325.

4- Maroto-Morales A; Ramon M; GarciaAlvarez O; Soler AJ; MartinezPastor F; Perez-Guzman MD. and Garde JJ. (2010). Characteristics of ram (Ovis aries) sperm head morphometry using the sperm class analyzer. Theriogenology. 73:437-448.

5- Noorafsham A. and Karbalay-Doust S.(2010). A simple method for unbiased estimating of ejaculated sperm tail length in subjects with normal and abnormal sperm motility. Micron. 41:96-99.

6- Bamba, K. (1987). Evaluation of acrosomal integrity of boar spermatozoa by bright-field microscopy using an eosinnigrosin stain. Theriogenology. 29: 1245-1251.
7- Thienpont D; Rochette F. and Vanparijs OFJ. (1986). Diagnosing heleminthiasis by coprological examination. $2^{\text {nd }}$ edition. Janssen research foundation, Beerse. Belgium. PP: 26-27.

8- Yániz JL; Vicente-Fiel S; Capistrós S; Palacín I. and Santolaria P.(2012). Automatic evaluation of ram sperm morphometry. Theriogenology 77; 1343-1350.

9- Hidalgo M; Rodriguez I; Dorado J; Sanz, J. and Soler C. (2005). Effect of sample size and staining methods on stallion sperm morphometry by the Sperm Class Analyzer. Vet. Med. - Czech, 50 : 24-32.

10-Naoman UT; Ali AJ; Ibraheem IY.(2006). Using of white ginger (zingiber officinalis) to improve semen characteristics during storage at $4 \mathrm{C} .4^{\text {th }}$ conferences of veterinary medicine collage. Mosul. Iraq. Vol. 2: 335-343.

11-Azawi OI; Ismaeel MA.(). Effects of Seasons on Some Semen Parameters and Bacterial Contamination of Awassi ram Semen. Rep. Dom. Anim.

12-Kheradmand A; Babaei H.(2006). Effect of ewe breed on the reaction time and semen characteristics in the ram. Iran. J. Vet. Res. Vol. 7: 23-26.

13-Taha T A; Abdel-Gawad EI; Ayoub M A (2000). Monthly variations in some reproductive parameters of Barki and Awassi rams throughout 1 year under subtropical 
conditions:1. Semen characteristics and hormonal levels. Animal Science 71:317-321.

14-Paulino de Paz; María MataCampuzano E; Jorge Tizado Mercedes Álvarez; Manuel Álvarez-Rodríguez; Paz Herraez; Luis Anel.(2011). The relationship between ram sperm head morphometry and fertility depends on the procedures of acquisition and analysis used. Theriogenology 76: $1313-1325$

15-Yániz JL; Vicente-Fiel S; Capistrós S; Palacín I. and Santolaria P.(2012). Automatic evaluation of ram sperm morphometry. Theriogenology 77; 1343-1350.

16-Noakes DE; Parkinson TJ; England GCW. and Arthur GH. ( 2001). Normal reproduction in male animal. In: Arthur's Veterinary Reproduction and Obstetrics. Eds. 8th ed, Elsevier Sci Ltd. PP: 686701.

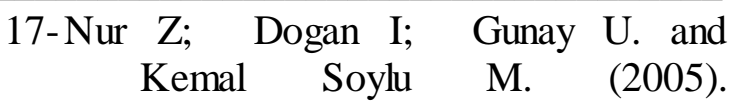
Relationships between sperm membrane integrity and other quality characteristics of the semen of saanen goat bucks. Bull Vet Inst Pulawy. 49: 183-187.

18-Hidalgo M. and Dorado J .(2009). Objective assessment of goat sperm head size by computerassisted sperm morphometry analysis (ASMA). Theriogenology. 87: 108-110.

19-Nagy SZ; Hazas G; Bali Papp A; Ivancsics J; Szasa F; Szasz JR; Kovacs A. and Foote RH. (1999). Evaluation of sperm tail membrane integrity by light microscopy. Theriogenology. 52:1153-1159.

20-Butts IAE; Ward MAR; Litvak MK; Pitcher TE; Alvari SMH; Tripple EA. and Rideout RM.(2011). Automated sperm head morphology analyzer for opensource software. Theriogenology .76: $1756-1761$.

\section{قياسات أطوال النطف في الكباش العواسية المحلية العراقية \\ عدي طلعت نعمان \\ كلية الطب البيطري/جامعة الموصل \\ الخلاصة}

أجريت الدراسة الحالية لمعرفة قياسات أطوال النطف في الكباش العواسية المحلية العراقية. خمسة أكباش عواسية عراقية محلية تراوحت أعمارها 2.5-4 سنة وأوزانها 37-44 كغم استعملت في هذه الدراسة. جمع السائل المنوي من الحيوانات باستعمال المهبل الاصطناعي. قيهت العينات مباثرة بعد عملية الجمع إذ تم تقييم حجم ولون العينة إضافة إلى تقييم الحركة الجماعية والحركة الفردية للنطف، نسبة النطف الحية والمشوهة إضافة إلى حساب تركيز النطف لمجموع القفات البالغ 30 قذفة. قياسات أطوال النطف تم أجراءها باستخدام مجهر الحقل المعتم والعسة العينية المدرجة. أظهرت نتائج قياسات أطوال النطف إن معدل طول رأس النطفة كان 99.62 1.2 مايكرون، عرض رأس النطفة 5.32 × 2.5 مايكرون، طول

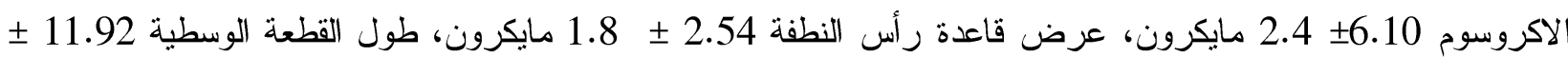
3.6 مايكرون عرض القطعة الوسطية 2.21 ـ 0.8 مايكرون، طول الذيل 50.62 × 2.1 مايكرون. كلمات مفتاحية: صفات السائل المنوي، قياسات وأطو ال النطف، الكباش العو اسية المحلية العراقية 